УДК 81.33

ББК 81.2

DOI: https://doi.org/10.17308/lic.2021.1/3246

\title{
ПАРАМЕТРИЧЕСКИЙ АНАЛИЗ ЧЕЧЕНСКО-РУССКОГО СЛОВАРЯ
}

\author{
А. А. Кретов, А. Д. Черечеча \\ Воронежский государственный университет
}

\section{PARAMETRIC ANALYSIS OF THE CHECHEN DICTIONARY}

\author{
A. A. Kretov, A. D. Cherechecha \\ Voronezh State University
}

\begin{abstract}
Аннотация: в статье рассматривается метод параметрического анализа лексики (ПАЛ), разработанный и реализованный Владимиром Тихоновичем Титовым, примененный к одному из представителей северо-кавказских языков - чеченскому. Главная задача данного метода - выделение 4 ядер лексики языка: функиионального (длина слова), синтагматического (количество фразеологизмов), парадигматического (количество синонимов) и эпидигматического (количество значений).

Ключевые слова: чеченский язык, параметрический анализ, стратификаџия, ядро, кавказские языки.

Abstract: the article considers the method of parametric vocabulary analysis (PVA), developed and implemented by Vladimir Tikhonovich Titov, applied to one of the representatives of the North Caucasian languages - Chechen. The main objective of this method is the allocation of 4 cores of language vocabulary: functional (word length), syntagmatic (number of phraseological units), paradigmatic (number of synonyms) and epidigmatic (number of definitions).
\end{abstract}

Key words: Chechen language, parametric analysis, stratification, core, Caucasian languages.

\section{Введение}

Количество этапных работ в области чеченской лексикологии не очень велико. Наиболее известной из них является книга А. Г. Мациева «Очерки лексикологии современного чеченского языка» [1]. В последнее время стали появляться работы, посвященные отдельным фрагментам (сельскохозяйственная, животноводческая, политическая, лингвистическая лексика, названия металлов и веществ и т. д.) или отдельным аспектам лексики чеченского языка: исследуются заимствования [2-4], неологизмы [5], фразеология [6-8], синонимия [9] и антонимия [10] или - в этимологическом аспекте - исконная лексика [11]. Видимо, следует согласиться с мнением Т. Х. Абдулазимовой, писавшей в 2007 г.: «Всестороннее... изучение семантики [мы бы сказали - и лексики. $A . K$ и $A$. Ч.] чеченского языка является актуальной задачей» [9].
Опыты целостного изучения лексико-семантической системы чеченского языка нам не известны, что и определяет актуальность данного исследования.

Цель исследования - параметрическая стратификация чеченской лексики.

Объектом исследования послужил «Чеченско-русский словарь» А. Г. Мациева [12], который был превращен в базу данных в формате электронных таблиц MS Excel. Из рассмотрения исключались все отсылочные словарные статьи, не имеющие дефиниций, словарные статьи, описывающие онимы и отонимические производные, аббревиатуры, а также все слова, кроме существительных, прилагательных, причастий и глаголов, - служебные слова (частицы речи), местоимения, числительные, деепричастия и наречия. В результате была сформирована база данных объемом 11097 слов, явившаяся объектом дальнейшего анализа.

(C) Кретов А. А., Черечеча А. Д., 2021

Контент доступен под лицензией Creative Commons Attribution 4.0 License.

The content is available under Creative Commons Attribution 4.0 License. 
Предмет исследования - системные связи чеченской лексики: синтагматические, парадигматические, эпидигматические и функциональные.

Метод исследования - параметрический анализ лексики (ПАЛ), многократно описанный и прошедший серьезную научную апробацию на самом высоком научном уровне, включая международный [1319].

\section{Функциональная стратификация чеченской лексики}

Функциональный вес слова косвенно определяется по его длине. При этом (на основании наблюдения Дж. К. Ципфа [20], многократно подтвержденного на текстах разных языков) считается, что функциональный вес слова обратно пропорционален его длине: чем слово короче, тем больше его Ф-вес и наоборот. Вес самого длинного слова принимается равным 0. Вес самых коротких слов максимально близок к 1 .

Bce 4 частнопараметрических веса «каждого из слов определяются как вес ранга его частоты по формуле

$$
P r_{i}=\frac{\Sigma r-R_{1-i}}{\Sigma r},
$$

где $\Sigma r$ - сумма единиц всех рангов, $R_{1-i}$ - сумма единиц от первого до данного, а $P r_{i}$ - вес $i$-го ранга. В данном случае речь идет о рангах частот, а не о рангах слов» [13-14]. Частоты при этом даются в порядке убывания параметрического веса: при функциональной стратификации - в порядке возрастания длины, при синтагматической, парадигматической и эпидигматической - в порядке убывания числа фразеосочетаний, синонимов или значений.

При определении длины лемм последние брались в практической транскрипции - без знаков препинания (пробелов, тире, символов омонимии и знака «*»)), а диграфы (буквы, состоящие из двух символов) заменялись одним символом (табл. 1).

Т а б ли ц а 1

Распределение чеченских слов по длине в словаре-источнике

\begin{tabular}{|c|c|c|c|}
\hline Букв & Слов & Накопл. & Ф-вес \\
\hline $\mathbf{1}$ & $\mathbf{3}$ & $\mathbf{3}$ & $\mathbf{0 , 9 9 9 7 3}$ \\
\hline $\mathbf{2}$ & $\mathbf{9 6}$ & $\mathbf{9 9}$ & $\mathbf{0 , 9 9 1 0 8}$ \\
\hline $\mathbf{3}$ & $\mathbf{4 9 5}$ & $\mathbf{5 9 4}$ & $\mathbf{0 , 9 4 6 4 7}$ \\
\hline $\mathbf{4}$ & $\mathbf{1 0 9 9}$ & $\mathbf{1 6 9 3}$ & $\mathbf{0 , 8 4 7 4 4}$ \\
\hline 5 & 1600 & 3293 & 0,70325 \\
\hline 6 & 1511 & 4804 & 0,56709 \\
\hline 7 & 1588 & 6392 & 0,42399 \\
\hline 8 & 1497 & 7889 & 0,28909 \\
\hline 9 & 1141 & 9030 & 0,18627 \\
\hline
\end{tabular}

\begin{tabular}{|c|c|c|c|}
\hline 10 & 843 & 9873 & 0,11030 \\
\hline 11 & 532 & 10405 & 0,06236 \\
\hline 12 & 297 & 10702 & 0,03560 \\
\hline 13 & 159 & 10861 & 0,02127 \\
\hline 14 & 112 & 10973 & 0,01117 \\
\hline 15 & 57 & 11030 & 0,00604 \\
\hline 16 & 28 & 11058 & 0,00351 \\
\hline 17 & 22 & 11080 & 0,00153 \\
\hline 18 & 7 & 11087 & 0,00090 \\
\hline 19 & 2 & 11089 & 0,00072 \\
\hline 20 & 4 & 11093 & 0,00036 \\
\hline 23 & 1 & 11094 & 0,00027 \\
\hline 25 & 1 & 11095 & 0,00018 \\
\hline 26 & 1 & 11096 & 0,00009 \\
\hline 28 & 1 & 11097 & 0,00000 \\
\hline
\end{tabular}

Поскольку для функционального анализа лексики важно количество звуков в лемме, а не их качество, а чеченский алфавит построен по принципу «одна фонема - одна буква», диграфы, содержащие символы $Z$ и $b$, при практическом транскрибировании превращались в монографы сплошным удалением этих символов; буква $K x$ заменялась на $Q$, а $2 I, \kappa I, n I$, $m I, x I, u I$, чI превращались в монографы адресным удалением символа $I$ : вне позиций после $2, \kappa, n, m, x$, $u$, ч символ $I$ сохранялся.

Наглядно распределение чеченской лексики по длине представлено на рис. 1.

Распределение лексики в словаре-источнике является двувершинным: мода - 5 букв - 1600 слов и второй пик - 7 букв - 1588 слов. Расхождение в 12 слов трудно назвать сколь-либо существенным.

В практике параметрического анализа за Ф-ядро языка принимается множество самых коротких слов максимально близкое 1000 , но не меньше этой величины. Таким образом, за Ф-ядро чеченской лексики следует принять 1693 полнозначных слова длиной не более 4 букв. Остальные ограничения, накладываемые на лексику при параметрическом анализе, были изложены выше.

Распределение чеченской лексики по Ф-весу представлено на рис. 2.

Слова с максимальным частнопараметрическим весом при параметрическом анализе лексики принято называть доминантами, а слова со вторым по величине параметрическим весом - вице-доминантами.

По Ф-весу со-доминантами являются слова $\overline{\boldsymbol{o}} \boldsymbol{b}$ 'тройка, три альчика', $\boldsymbol{y}$ 'доска' и ю 'ударник (оружия или орудия)'.

Что касается со-вице-доминант, то их 96: $\boldsymbol{a}$ 'голос'; $\boldsymbol{\sigma} \overline{\boldsymbol{a}}$ 'поцелуй'; $\boldsymbol{\sigma} \overline{\boldsymbol{\sigma}} \boldsymbol{b}$ 'горный 'чеснок'; $\boldsymbol{\sigma} \overline{\boldsymbol{\sigma}}$ 'сирота'; za 'ветка, 'ветвь'; гав 'круп '(лошади)'; ге 'пядь

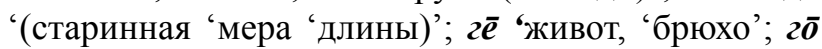




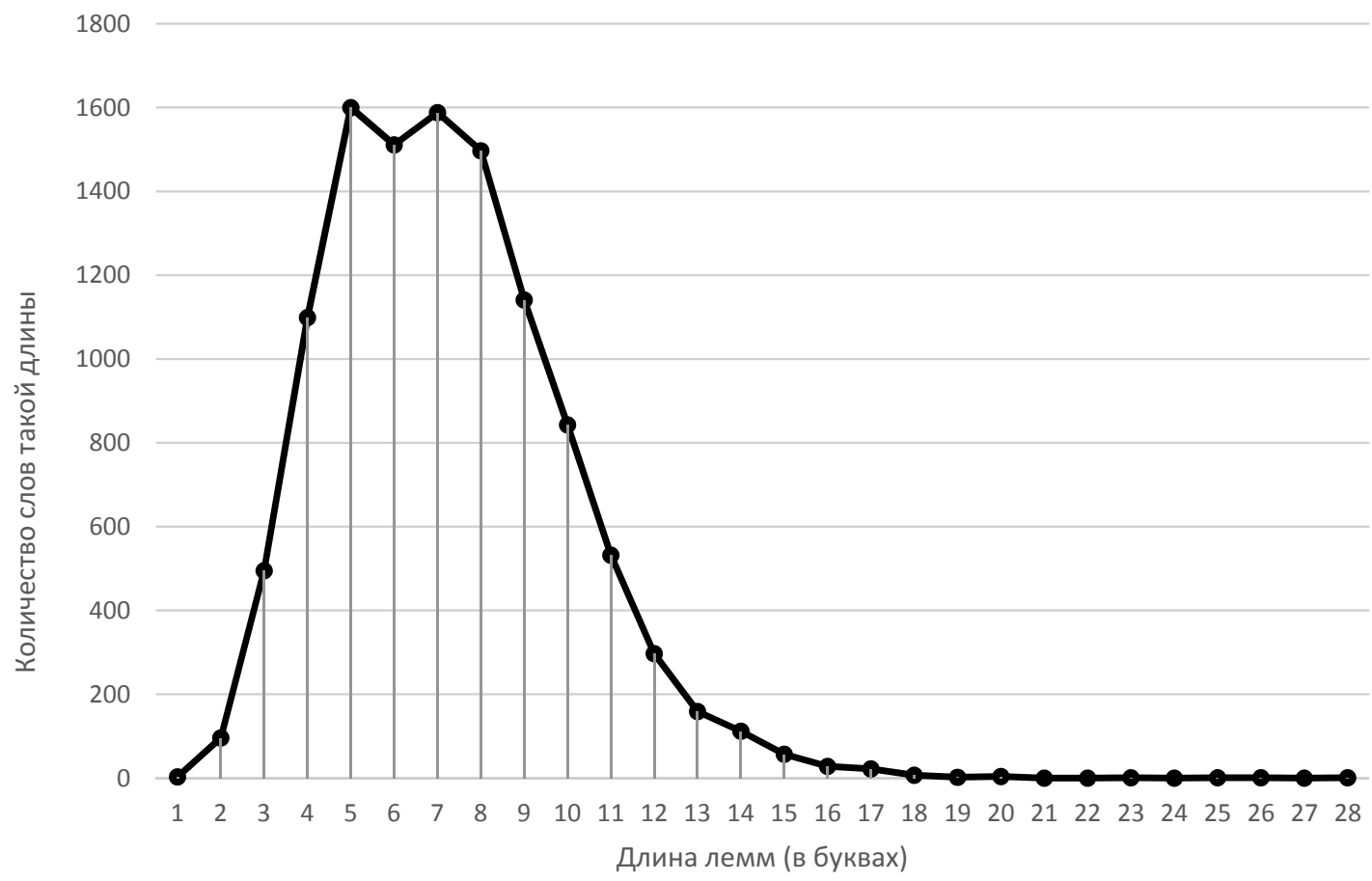

Puc. 1. Распределение чеченской лексики по длине (нарицательные имена и глаголы)

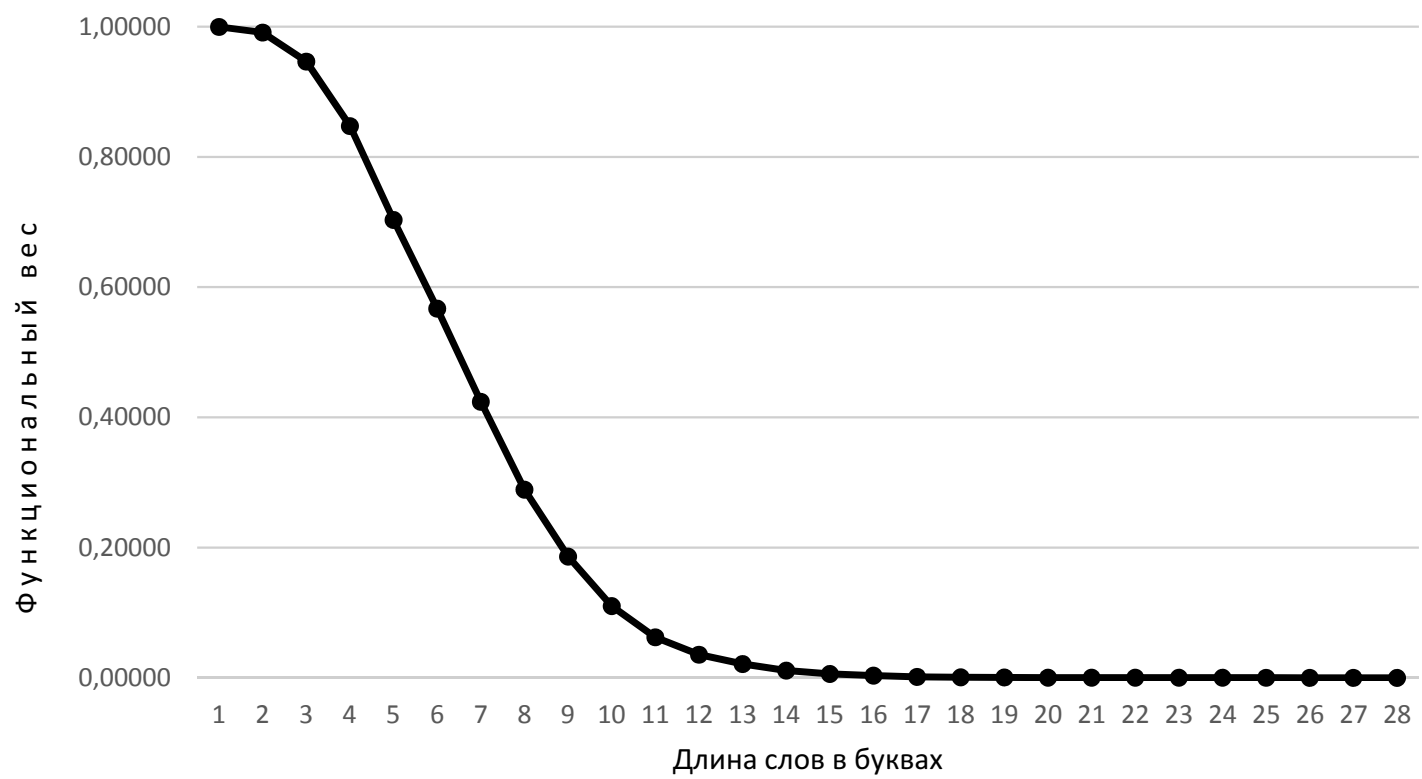

Рuc. 2. Распределение чеченской лексики по Ф-весу 


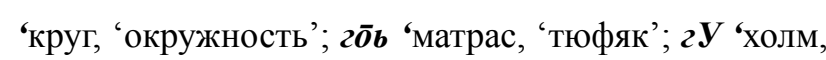
'курган'; гІа 'лист’; гІо1 'помощь, ‘поддержка, 'со-

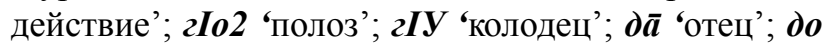
'ушная 'сера'; до 'кукурузохранилище '(плетеная 'из 'прутьев 'сапетка 'для 'хранения 'кукурузы 'в 'початках)'; де1 'день'; де2 'возможность '(что-л. 'сде-

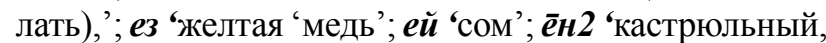
'котельный’; жа 'отара'; зу 'еж’; ка1 ‘удача, 'сила'; ка2 'баран-производитель '(старше 'двух 'лет)'; ко 'пук 'пшеницы, 'скошенной 'одним 'взмахом 'серпа'; $\boldsymbol{\kappa} \boldsymbol{x \boldsymbol { a }}$ 'участок 'пахотной 'земли'; кхав 'радостная 'весть'; кхо 'помет '(крупного 'рогатого 'скота)'; $\boldsymbol{\kappa} \boldsymbol{x} \boldsymbol{O \boldsymbol { b }}$ 'фасоль'; къa 'грех’; къy 'вор, 'воровка'; кIa

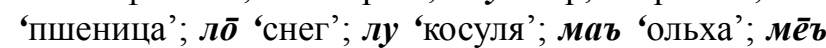
'молодка, 'молодая 'курица'; м⿻ 'шрам, 'рубец '(от 'зажившей 'раны)'; ов1 'вертел'; ов3 'невод’; ор 'яма'; оькx 'ногайские 'шерстяные 'валенки'; оьс 'кладка 'из 'трех 'снопов'; cal ‘зрение'; ca2 'душа, 'дух'; ca3 'угол'; ca4 'выгода, 'польза, 'прибыль'; $\boldsymbol{c} \overline{\boldsymbol{e}}$ 'поросль, 'молодые 'ветки, 'се 'баб 'накормить 'молодыми 'ветвями '(козлят 'и т. п.)'; то 'баран 'в 'возрасте 'более 'одного 'года'; mIa 'передняя 'нога '(животного)'; $\boldsymbol{m} \boldsymbol{I} \overline{\boldsymbol{e}}$ 'поверхность 'чего-л.'; $\boldsymbol{m} \boldsymbol{I} \ddot{\boldsymbol{e}}$ 'провести 'через 'мост'; mIo 'щёбень'; $\boldsymbol{m I} \boldsymbol{\text { o }}$ 'сметана'; $\boldsymbol{y \boldsymbol { I } I}$ 'вой '(волка)'; $\boldsymbol{y \boldsymbol { H }}$ 'инфекция, 'зараза'; $\boldsymbol{x \boldsymbol { a } 1}$ 'бок'; $\boldsymbol{x a 2}$ 'ка-

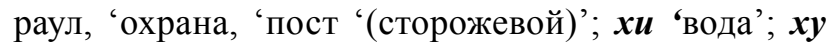

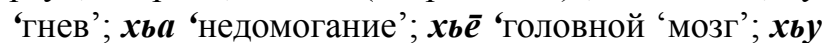
'воспаление 'раны '(вызванное 'холодом, 'сыро-

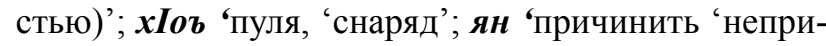
ятность'; це 'зуб '(у 'лошади)'; цIa 'комната'; цIе2 'имя'; $\boldsymbol{ц} \boldsymbol{I y}$ 'божество '(у 'язычников)'; ча2 'медведь';

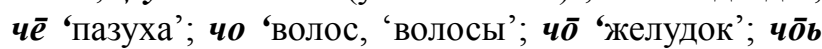
'внутренность, 'внутреннее 'помещение'; иІо̄ь 'ларь '(для 'ссыпки ‘зерна)'; иІу ‘шомпол'; ша2 ‘старинная 'мера 'длины, 'равная 'расстоянию 'между 'растянутыми 'большим 'пальцем 'и 'мизинцем'; жо 'год'; шу 'холм, 'возвышенность'; эн 'смешаться, 'смешиваться’; эр ‘борзая’; эх 'стыд, 'смущение’; юкъ2 'зола'; юм 'галоп '(аллюр)'; юьхьI 'конец’; юьхь3 'лицо'; яй 2 'рыба 'из 'семейства 'карповых'; ял2 'загривок, 'холка'; ял3 'облегчение'; ян2 'еж'; яхь 'соревнование'; Ia 'зима'; Iab 'пар “; Iy 'пастух'.

\section{Синтагматическая стратификация чеченской лексики}

Косвенным показателем синтагматической активности в словаре принимается количество словосочетаний с данным словом в его словарной статье: чем больше таких словосочетаний, называемых в практике ПАЛа фразеосочетаниями, сокращенно - ФС (в соответствии с традициями Воронежской фразеологической школы, основанной 3. Д. Поповой в соавторстве с М. М. Копыленко, фразеология понимается максимально широко - как лексическое учение о словосочетаниях, и фразеосочетанием называются любые сочетания слов - от самых свободных до самых неразрывных). Распределение чеченских слов по количеству фразеосочетаний представлено в табл. 2.

Т а б л и ц а 2

Распределение чеченских слов по количеству ФС в словаре-источнике

\begin{tabular}{|c|c|c|c|}
\hline ФС & Слов & Накопл. & С-вес \\
\hline 21 & 1 & 1 & 0,99991 \\
\hline 16 & 1 & 2 & 0,99982 \\
\hline 14 & 1 & 3 & 0,99973 \\
\hline 13 & 2 & 5 & 0,99955 \\
\hline 10 & 3 & 8 & 0,99928 \\
\hline 9 & 2 & 10 & 0,99910 \\
\hline 8 & 2 & 12 & 0,99892 \\
\hline 7 & 3 & 15 & 0,99865 \\
\hline 6 & 7 & 22 & 0,99802 \\
\hline 5 & 9 & 31 & 0,99721 \\
\hline 4 & 80 & 111 & 0,99000 \\
\hline 3 & 212 & 323 & 0,97089 \\
\hline 2 & 605 & 928 & 0,91637 \\
\hline 1 & 2043 & 2971 & 0,73227 \\
\hline 0 & 8126 & 11097 & 0,00000 \\
\hline
\end{tabular}

Наглядно стратификация чеченской лексики по C-весу (синтагматическому весу) представлена на рис. 3.

Количественный и качественный состав С-ядра определяется тем, что слов с двумя ФС меньше 1000 928. Это обстоятельство заставляет нас включить в С-ядро все слова, представленные в словаре хотя бы одним ФС, что составляет 2971 лексическую единицу.

Синтагматической доминантой (по данным словаря) является слово бІаьрг 'глаз' с 21 фразеосочетанием: бІаьргли бехкарех ловзар игра в жмурки; ас бІаьрг буьзна иуьнан ницкъах я восхищен его силой; бІаьрг буза импонировать; бІаьрг хилийта сглазить; бІаьргех хи да̄ла прослезиться; бІаьрг болу ба̄сма ситец горошком; меттигах бІаьрг то̄ха обозреть местность, в) мигнуть глазом, моргнуть, г) присмотреться, приглядеться; коррана бІаьрг торха застеклить окно, б) обозреть, охватить взором; бІаьрг то̄ха а) застеклить; ко̄ран бІаьрг оконное стекло; бІаьргашна иІий доьссина глаза налились кровью; бІаьрг иза maIou глазом не моргнув; бІаьрг maĪ̄ а) моргнуть, б) бросить взгляд; бІаьрган куьзганаш очки, пенсне; бІаьргаш детта а) мигать, моргать, б) устремлять взор; бІаьрг бетта окидывать взором, обозревать; бІаьрг балла ослепнуть (букв. лишиться глаза); бІаьргаш хьаббан закрыть глаза; бІаьргаш къарзо̄ вытара- 
1,2

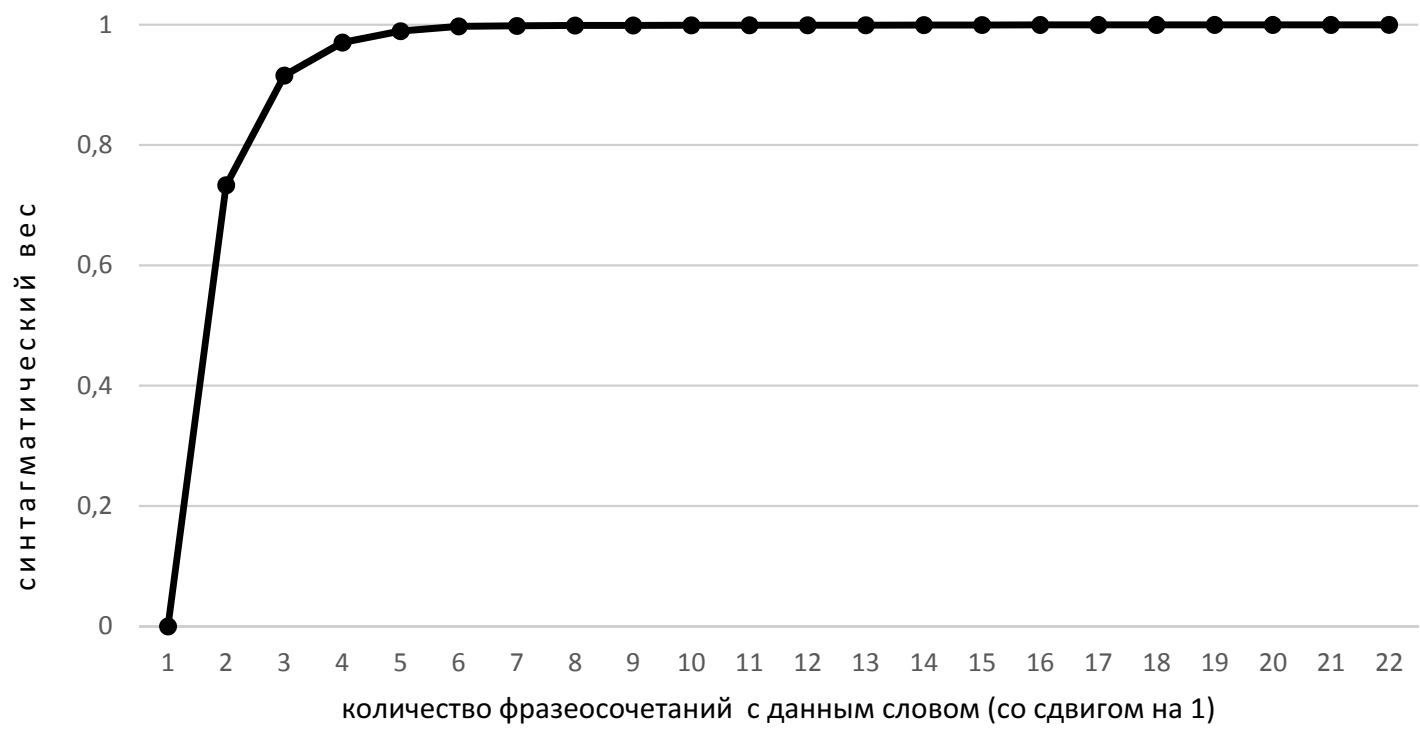

Puc. 3. Распределение чеченской лексики по синтагматическому весу

щить глаза; бІаьргаш белла открыть глаза; жугІар-бІаьргаш карие глаза.

Синтагматической вице-доминантой, по данным словаря-источника, является слово бага ${ }^{2}$ 'рот' с 16 фразеосочетаниями: бага са а кхаьчна впопыхах; бага даха стать предметом людской молвы, притчей во языцех; доттагІчо̄ беллачу динна бага ма хьежа посл. подаренному другом коню в рот не смотри; бага юьззина полон рот; бага хоа поместиться во рту, помещаться во рту; бага хи кхарза полоскать рот; бага дотта налить в рот чего-л.; бага дола положить в рот что-л.; багара да̄ла а) выпасть изо рта, б); иуьнан багара дош даккха хала ду у него трудно изо рта слово вытянуть; багара даккха а) вытащить, вырвать что-л; бага а гІиттош ладийгІар слушать разинув рот, б) зевать; бага гІитто̄ а) разевать рот; бага гІатто̄ а) разинуть рот, б) зевнуть; бага ма лёе а) не болтай, б) не бранись; бага лёян а) болтать, б) ругаться, произносить бранные слова, в) ворчать.

\section{Эпидигматическая стратификация чеченской лексики}

Эпидигматический вес слова оценивается по количеству значений, выделенных у него в словаре: чем больше у слова значений, тем больше его эпидигматический вес.

Распределение чеченской лексики по количеству значений (и, соответственно, по эпидигматическому весу) представлено в табл. 3 .
Т а б ли и а 3

Распределение чеченской лексики по количеству значений

\begin{tabular}{|c|c|c|c|}
\hline Значений & Слов & Накопл. & Э-вес \\
\hline $\mathbf{1 0}$ & $\mathbf{1}$ & $\mathbf{1}$ & $\mathbf{0 , 9 9 9 9 1}$ \\
\hline $\mathbf{9}$ & $\mathbf{1}$ & $\mathbf{2}$ & $\mathbf{0 , 9 9 9 8 2}$ \\
\hline $\mathbf{8}$ & $\mathbf{2}$ & $\mathbf{4}$ & $\mathbf{0 , 9 9 9 6 4}$ \\
\hline $\mathbf{6}$ & $\mathbf{2}$ & $\mathbf{6}$ & $\mathbf{0 , 9 9 9 4 6}$ \\
\hline $\mathbf{5}$ & $\mathbf{1 1}$ & $\mathbf{1 7}$ & $\mathbf{0 , 9 9 8 4 7}$ \\
\hline $\mathbf{4}$ & $\mathbf{4 2}$ & $\mathbf{5 9}$ & $\mathbf{0 , 9 9 4 6 8}$ \\
\hline $\mathbf{3}$ & $\mathbf{2 3 0}$ & $\mathbf{2 8 9}$ & $\mathbf{0 , 9 7 3 9 6}$ \\
\hline $\mathbf{2}$ & $\mathbf{1 4 2 8}$ & $\mathbf{1 7 1 7}$ & $\mathbf{0 , 8 4 5 2 7}$ \\
\hline 1 & 9380 & 11097 & 0,00000 \\
\hline
\end{tabular}

Наглядно стратификация чеченской лексики по Э-весу в словаре-источнике представлена на рис. 4.

Эпидигматической доминантой чеченской лексики (по данным словаря-источника) является глагол $\boldsymbol{\kappa} \boldsymbol{x} \boldsymbol{E m a}$, имеющий 10 значений: 1) взойти, всходить (о небесных светилах); 2) засиять, сиять, светить, излучать свет (о небесных светилах); 3 ) зайти, заходить (по пути); 4) попасть, попадать в кого, во что-л.; 5) удариться, ударяться обо что-л.; 6) понять, понимать; 7) усвоить, усваивать; 8) освоить, осваивать; 9) заболеть, заболевать; 10) впасть, впадать; втечь, втекать.

Эпидигматической вице-доминантой чеченской лексики (по данным словаря-источника) является глагол къасто, имеющий 9 значений: 1) отделить; 2) расчленить; 3) разобщить; 4) разнять; 5) разлучить; 
1,20000

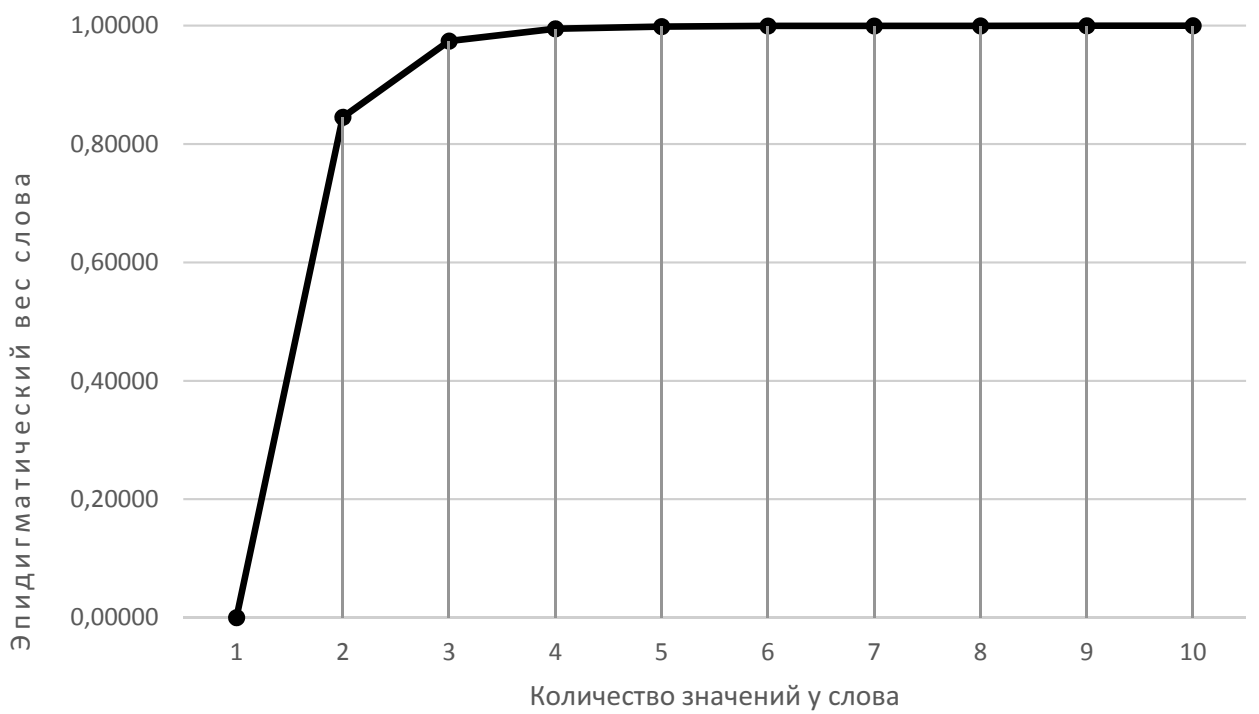

Puc. 4. Распределение чеченской лексики по эпидигматическому весу

6) развести (супругов); 7) определить, уточнить, установить; 8) выбрать, выделить, отличить; 9) разобрать, рассмотреть.

Эпидигматическое ядро лексики по данным словаря-источника образуют 1717 слов с 2 и более значениями.

\section{Парадигматическая стратификация чеченской лексики}

Парадигматический вес слова в ПАЛе оценивается по максимальному количеству его синонимов в одном из его значений (если слово многозначно). Если у слова одно значение, такая оговорка излишня.

Поскольку парадигматический вес (П-вес) слова оценивается по размеру синонимического ряда, в который оно входит хотя бы одним из своих значений, следует обозначить понимание синонимии, реализуемое в данном исследовании. Прежде всего отметим, что синонимами признаются только универбы, и не признаются синонимичные им словосочетания. Практика включения в синонимический ряд словосочетаний встречается в различных словарях синонимов, но поскольку целью исследования является выделение ядерной лексики языка, то нет необходимости учитывать словосочетания, относящиеся к номинативной периферии лексико-семантической системы.

Поскольку наша задача - «взвесить» парадигматический потенциал слова, а не дать рекомендации по его словоупотреблению, мы можем себе позволить дать синонимам процедурно-технологическое опре- деление: синонимами признаются слова, дефиниции которых совпадают не менее чем наполовину.

В чеченско-русском словаре чеченские слова представляют язык, а русские - метаязык его описания. Следовательно, в этом словаре русские слова выступают в качестве метаслов. Это позволяет уточнить наше определение: синонимами признаются слова, в дефинициях которых совпадает не менее 50 \% метаслов.

Например, слова авшпаш 'ложь, неправда' и nуьчаш 'ложь, неправда' имеют по одному значению и толкуются двумя одинаковыми метасловами. На этом основании они признаются синонимами. А слово харилер имеет два значения, одно из которых толкуется одним метасловом 'ложь'. В этом значении слово харщлер признается синонимом словам авшпаш и пуьчаш.

В парадигматическую базу данных (и в парадигматическое ядро словаря) каждое слово входит столько раз, сколько дефиниций оно имеет. (При этом мы не различаем эквиваленты и дефиниции: любая цепочка метаслов в двуязычном словаре считается $\partial e$ финицией.)

Так, например, слово кхиа, имеющее 8 значений, половиной из них входит в 4 разных синонимических ряда: 6-членный, 4-членный и в два 2-членных.

1. кхиа (8 значений) 'вырасти, расти';

2. довла (3 значения) 'вырасти (о растениях)';

3. хьалакхиа (1 значение) 'вырасти, подрасти';

4. да্ла (3 значения) 'вырасти, расти (о растениях)'; 
5. лакхада̄ла (2 значения) 'вырасти, стать выше ростом';

6. лакхадовла (2 значения) 'вырасти, стать выше ростом'.

1. кхиа 'созреть, зреть';

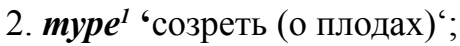

3. хила 'созреть, зреть, поспеть, спеть';

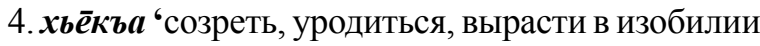
(о плодах, злаках).

1. кхиа 'понять, понимать';

2. кxEma' 'понять, понимать.

1. кхиа' 'развиться, развиваться';

2. тился 'развиться, развиваться (о промышленности, культуре и т. п.)'.

Приведенный пример дает несколько оснований для уточнения формулировки формализации процесса выделения синонимических рядов по данным словаря-источника.

1. Сведения в скобках игнорировать - считать их не существующими. В приведенных примерах это -

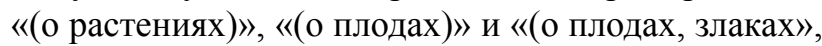
«(о промышленности, культуре и т. п.)».

2. Единицей дефиниции считать только последовательности символов, разделенные запятой или точкой с запятой. Метаслова, разделенные пробелами, считать одной единицей толкования. В приведенных примерах это относится к случаям «стать_выше_ростом» и «вырасти_в_изобилии».

3. Видовые пары в метаязыке считать одной единицей толкования. В приведенном примере это «вырасти-расти», «созреть-зреть», «поспеть-спеть», «понять-понимать» и «развиться-развиваться».

При таких решениях все единицы 6-членного синонимического ряда следует признать синонимами.

4. Но даже при таких решениях, позволяющих признать синонимами туре 1 'созреть (о плодах)' и хила 'созреть-зреть, поспеть-спеть', у которых число общих единиц метаязыка совпадают на 50 \%, формальный анализ не позволит включить в число синонимов этого ряда глагол хвёкъа 'созреть, уродиться, вырасти_в_изобилии (о плодах, злаках)', имеющий 3 единицы метаязыка, из которых только одна совпадает с остальными метаязыковыми единицами членов синонимического ряда: кхиа 'созреть-зреть'; туре ${ }^{1}$ 'созреть (о плодах)'.

5. В таких случаях остается два варианта: 1) быстрый, но ненадежный - учитывать только первое слово дефиниции и 2) надежный, но медленный ручной режим принятия решений. Некоторый выигрыш во времени дает сочетание первого варианта со вторым.
6. С теоретической точки зрения целесообразно различать синонимы и разного рода фонетические и грамматические варианты одного и того же слова. Так, например, больше оснований считать синонимами лексемы глядеть-смотреть или поглядеть-посмотреть, чем глядеть-глянуть-поглядеть-взглянуть, с одной стороны, или смотреть-посмотреть с другой.

Из этого следует вывод: синонимы - это слова с разными корнями. В таком случае следует ввести формализм, позволяющий отличать по формальным признакам синонимы от вариантов слова. Учитывая то обстоятельство, что «в морфологической структуре имен и глаголов префиксальные показатели являются более древними по сравнению с суффиксальными» и «наблюдается тенденция уменьшения удельного веса префиксации и увеличение удельного веса флективности и суффиксации» [21], можно принять следующий алгоритм выделения псевдо-синонимов: с ин они мами не признантся слова, у которых большая часть начальных с и м в о ло в со в п а да е т.

Поскольку наиболее продуктивные префиксы (например, хьала- 'вверх', mIе̄- 'на', кIёл- 'под', дІа'от' [22]) встречаются в глагольных основах и имеют не лексическое, а грамматическое значение, подобное значениям пространственных падежей, маркируемых показателями локации и направления [23], то их можно задать списком и (при решении вопроса о синонимичности/несинонимичности лексем) не учитывать при подсчете начальных символов. Например, mе-кxётар; 'увеличение, повышение (зарплаты)' и mle-moxхар; 'увеличение, повышение (например, зарплаты)' - самые настоящие синонимы.

Зато из числа синонимов придется исключить пару лакхада̄ла 'вырасти, стать выше ростом' и лакхадовла 'вырасти, стать выше ростом', поскольку инициаль лакхад- (6 символов) у них общая, а финали -йла (3 символа) и -овла (4 символа) уступают ей по длине. Из двух лемм в синонимическом ряде надо оставить лишь одну - более короткую.

Таким образом, первый синонимический ряд следует признать не шести-, а пятичленным.

Соответственно, формально выделенный 5-членный синонимический ряд «паргIamd-аккхар 'успокоение', паргIатд-алар 'успокоение', паргIamd-ийлар 'успокоение', паргІатд-овлар 'успокоение', тер 'успокоение'» придется сократить до 2-членного: паргІатдалар 'успокоение' и тер 'успокоение'. Основание - инициаль паргIamd- содержит 8 символов, а самая длинная финаль - -аккхар содержит 6 символов. Рассмотрение инициали паргIamd- на фоне словаря-источника позволяет уточнить наше представление о составе основы: napzIam 1. прил. 1) удобный; 2) спокойный; 3) свободный; 4) просторный; 
2. нареч. 1) удобно; 2) спокойно; 3 ) свободно, непринужденно.

В «синонимическом ряде» «совд-аккхар 'увеличение, повышение', совд-алар 'увеличение, повышение', совд-ийлар 'увеличение, повышение', совд-овлар 'увеличение, повышение'» наш алгоритм дает сбой: ни в одном из слов финициаль совд- (4 символа) не длиннее финали.

Выбора два: либо считать эти слова синонимами, имеющими «разные» корни, либо снять ограничение на длину инициали, что автоматически приведет к признанию вариантами любых двух слов с одинаковой дефиницией, начинающихся с одной буквы - например, кхиа 'понять, понимать' и кxEma 'понять, понимать'.

Отказ от этой альтернативы означает усложнение алгоритма: корень надо искать среди слов такой же или отличающейся на +/- 1 символ длины. Это чревато ошибками, связанными с омонимией. Задача же компьютерного выявления слов со «схожей» семантикой вряд ли может быть корректно формализована.

Остается тот же ручной режим, в котором мы может не только найти корневое слово - сов нареч. 'больше, более', но и предположить наличие того же корня в словах совгIam [совгІатан, совгІатна, совгІато, совгIame, $\partial ;$ мн; совгIamau, d] 1) дар, подарок; 2) награда; совгIam дан а) подарить, дарить; б) наградить; совгІатан прил.; подарочный; совгІатана нареч.; 1) в дар, в подарок; 2) в награду; совгІатлург прич. 1) дарящий; 2) награждающий. В случае корректности такого предположения кортеж сов- можно интерпретировать как корень, а примыкающие к нему -д и -гI - либо как самостоятельные морфемы, либо как расширители корня - детерминативы, либо как совпадающие части всех последующих морфем.

При обсуждении проблемы синонимии трудно удержаться от комментирования тех или иных лексикографических решений. Так, например, толкования слов йилбазкІудал 'вид сорной травы' и тати 'вид сорной травы’ тождественны, но ведь это не синонимы, а в лучшем случае эквонимы. Содержательно к ним примыкают и слова: жакъжакъ-буц 'вид сорняка' и кондар 'разновидность сорной травы'. Носители чеченского языка знают эти травы и значения этих слов, а носителям русского языка по таким дефинициям никогда не догадаться, о каких сорняках идет речь. Тут помогла бы распространенная в лексикографии практика давать латинский ботанический термин, что позволяет точно идентифицировать растение. Порой в словаре дается уточнение: бурса 'вид кустарника', а жагІнакх 'вид кустарника с красными мелкими плодами’. Красные мелкие плоды, например, у барбариса. Но ведь у красной смородины - тоже. А о кустарнике бурса и этого не известно.
Видимо, дефиниций типа «Вид Х», «Разновидность Х» в словарях следует избегать (если, разумеется, нас интересует семантика слов входного языка, а не их примерная тематическая принадлежность).

Реализация вышеизложенных принципов парадигматической стратификации чеченской лексики представлена в табл. 4.

Т а б ли ц а 4

Парадигматическая стратификаиия чеченской лексики

\begin{tabular}{|c|c|c|c|}
\hline Слов & Рядов & Накопл. & П-вес. \\
\hline $\mathbf{5}$ & $\mathbf{5}$ & $\mathbf{5}$ & $\mathbf{0 , 9 9 9 5 9}$ \\
\hline $\mathbf{4}$ & $\mathbf{2 0}$ & $\mathbf{2 5}$ & $\mathbf{0 , 9 9 7 9 7}$ \\
\hline $\mathbf{3}$ & $\mathbf{9 8}$ & $\mathbf{1 2 3}$ & $\mathbf{0 , 9 9 0 0 0}$ \\
\hline $\mathbf{2}$ & $\mathbf{6 1 0}$ & $\mathbf{7 3 3}$ & $\mathbf{0 , 9 4 0 4 0}$ \\
\hline 1 & 11566 & 12299 & 0,00000 \\
\hline
\end{tabular}

Наглядно распределение синонимических рядов по числу составляющих их слов и, как следствие, по парадигматическому весу представлено на рис. 5 .

Парадигматический параметр интересен тем, что он позволяет «взвесить» важность тех или иных понятий (концептов) в языковом сознании его носителей: чем важнее то или иное понятие, представленное конкретными языковыми значениями, чем сильнее эмоции, с ним связанные, тем надежнее оно защищено в лексико-семантической системе языка, тем многократнее оно в ней дублируется, и, следовательно, тем больше слов в синонимическом ряду, образуемом данным значением.

К сожалению, информация о синонимических связях, полученная в результате анализа данных словаря, обладает небольшой глубиной: максимальный размер синонимического ряда -5 лексем. Таких синонимических рядов выявлено 5. И все они могут быть причислены к парадигматическим доминантам чеченской лексики (по данным словаря-источника).

Парадигматическими доминантами чеченской лексики оказались следующие семемы, образующие 5-членные синонимические ряды: 1) 'наблюдательный': тІа̄ламберг, сакх, тидаме̄, Іуналлин, тергамё; 2) 'наблюдение': mІехьовсар, зер, тІехьажар, тIалам, терго; 3) 'обида': ӧьгІазло, моха1, халахётар, дегабаам, вас; 4) 'приблизиться': гергада̄н, уллёгІорта, тІехила, юххёдахка , улледан; 5) 'куча': барз, овла, сал, чалх, жІуга'.

Эти П-доминанты свидетельствуют о таких аксиологемах чеченского народа, как н а б л ю д а т е л ьн о с т ь, $з$ о р к о с т ь, р а с у д и те ль н о с т ('наблюдательный', 'наблюдение'), ч у в с т в о с о б с т в ен н о го д о с т и н с т а, горд о с т, о которых свидетельствует маркированность семемы 'обида', а также ц е ле у с тремл ен н о с ть, д е ят е ль н о с т ь, м о б и л ь н о с т ь ('приблизиться'). 


\section{1,20000}

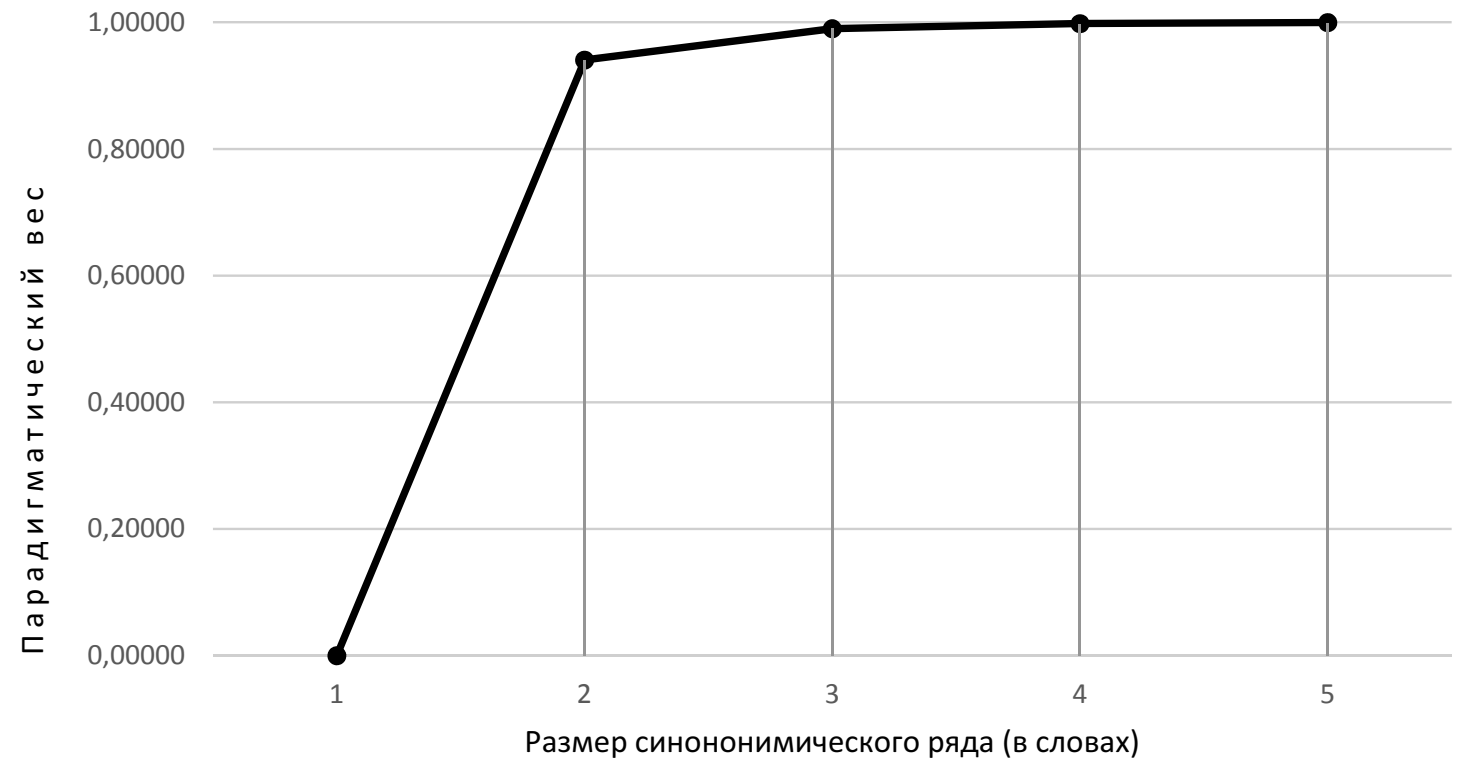

Puc. 5. Распределение синонимических рядов по парадигматическому весу

Семема 'куча' является одним из холизмов - обозначений целостных множеств однородных предметов (кстати сказать, одним из наиболее распространенных множеств в традиционном жизненном укладе). Если первые 4 семемы связаны с константами лексико-семантической системы, то последняя семема относится к переменныл этой системы, к так сказать, «грамматике» лексико-семантической системы языка.

К вице-доминантам лексико-семантической системы относятся члены 4-членных синонимических рядов, образованных 20 семемами (см. ниже столбец «Семемы»).

\begin{tabular}{|l|l|l|}
\hline \multicolumn{1}{|c|}{ Семемы } & \multicolumn{1}{|c|}{ Аксиологемы } & \multicolumn{1}{c|}{ Кластер } \\
\hline 'оправдание' & Великодушие & Добродетели \\
\hline 'признание' & Великодушие & Добродетели \\
\hline 'удача' & $\begin{array}{l}\text { Оптимизм, удачли- } \\
\text { вость }\end{array}$ & Добродетели \\
\hline 'успокоиться' & Самообладание & Добродетели \\
\hline 'род' & Родство & Добродетели \\
\hline 'союз' & Единство, верность & Добродетели \\
\hline 'бережливость' & Хозяйственность & Добродетели \\
\hline 'износиться' & Хозяйственность & Добродетели \\
\hline 'нацелить' & Целеустремленность & Добродетели \\
\hline 'разорение' & Созидание & Добродетели \\
\hline 'косой' & Здоровье, красота & Добродетели \\
\hline 'верхний' & Горы & Среда обитания \\
\hline 'поднять' & Горы & Среда обитания \\
\hline 'подняться' & Горы & Среда обитания \\
\hline
\end{tabular}

\begin{tabular}{|l|l|l|}
\hline 'клен' & Дерево & Среда обитания \\
\hline 'кленовый' & Дерево & Среда обитания \\
\hline 'ухаб' & $\begin{array}{l}\text { Дорога; подвижный } \\
\text { образ жизни }\end{array}$ & Среда обитания \\
\hline 'баран' & Животноводство & Уклад \\
\hline 'ремень' & Животноводство & Уклад \\
\hline 'созреть' & Растениеводство & Уклад \\
\hline
\end{tabular}

К уже отмеченным аксиологемам цуелеустремленность ('нацелить') и мобильность ('подняться', 'поднять') добавляются такие аксиологемы, как великодушие ('оправдание', 'признание'), оптимизм и удачливость ('удача'), самообладание ('успокоиться'), родство ('род'), единство, верность ('союз'), хозяйственность ('бережливость', 'износиться'). Две аксиологемы чеченской ментальности выражены инверсным способом - через маркирование их нарушения. Это аксиологема созидание, выраженная через ее противоположность - семему 'разорение', и аксиологемы здоровье, красота, выраженные через семему 'косой' - одноглазый, т. е. увечный в отличие от здорового или 'прямой' как противопоставленный кривому-косому (и то и другое свойства недолжного и некрасивого). Синомический ряд семемы 'косой' имеет следующий состав: перс, раз, гІунжара, бІаьргкъуьда.

Семемы 'верхний', 'поднять' и 'подняться' характеризуют горы как среду обитания чеченского народа. Особенно здесь показательно движение не вниз, что легче, а вверх - что сложнее. Среду обитания харак- 
теризует и семема 'ухаб’ - выбоина на дороге, осложняющая движение. Эта семема характеризует не только среду обитания, но и подкрепляет уже отмеченную выше аксиологему мобильность.

Из всей окружающей растительности несколько неожиданно выделен 'клен' - не самое полезное в хозяйстве дерево. Его синонимический ряд состоит из следующих лексем: мавлказ, лёга1, къахк1, стайр. Возможно, разгадка этого явления содержится в традиционной материальной культуре и фольклоре чеченского народа.

Традиционный жизненный уклад представлен животноводством ('баран' и 'ремень' - «узкая и длинная полоса выделанной кожи барана или крупного рогатого скота») и растениеводством - семема 'созреть' - стать зрелым, т. е. «спелым, созревшим (о плодах, злаках, овощах)». Дополнением к животноводству и растениеводству служит также охота, о которой свидетельствует семема 'нацелить' и обра-

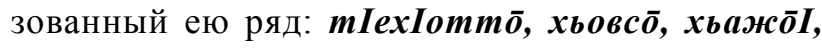

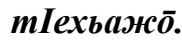

Вот такая информация об аксиологемах, среде обитания и образе жизни чеченского народа нашла отражение в словаре Ахмата Гехаевича Мациева.

Выше мы уже отмечали малую парадигматическую глубину исследованного материала. Для того чтобы ее увеличить и тем самым сделать стратификацию чеченской лексики более содержательной, мы можем воспользоваться таким параметром, как интегральный параметрический вес (ИП-вес), предложенным Ю. А. Стародубцевой, описавшей его следующим образом: «Для того чтобы определить П-вес семантемы (а значит, и представляющей ее лексемы-леммы), достаточно сложить число синонимов, входящих во все синонимические ряды, образуемые синонимами каждой из семем данного слова, и вычесть из этой суммы» (тут мы поправим автора. - A. К. и A. Ч.) число синонимических рядов, в какие входит данное слово: «ведь слово не может быть синонимом самого себя. Если этого не сделать, то число синонимов однозначного слова, не имеющего синонимов, будет равно 1 (мы сосчитаем лемму этого слова), если же это сделать, число синонимов у такого слова будет равно 0. А далее П-вес семантемы можно подсчитывать по той же формуле, что и прежде» [24].

При этом считается, что однозначное слово входит в «нулевой» синонимический ряд, состоящий из одной лексемы. Поэтому из числа лексем-синонимов в «нулевом» синонимическом ряде - 1, вычитается число значений однозначного слова -1 , что и дает искомый 0. Дело в том, что Ю. А. Суворова, видимо, полагала, что многозначное слово каждым из своих значений входит в какой-то синонимический ряд, но ведь может быть и так, что не все значения многознач- ного слова синонимизируются. Например, в словаре-источнике слово кІомсар имеет 3 значения, и каждое из них имеет по синониму. Следовательно, сумма синонимов в этих трех рядах $3 \times 2=6$. Из этой величины вычитаем число значений (или что то же самое в данном случае - число синонимических рядов). Получаем $6-3=3$.

Однако в том же словаре есть и слово кхиа с 8 значениями, входящее в 3 синонимических ряда: один 4-членный и два 2-членных. Складываем: $4+2+2=8$. Если мы вычтем число его значений -8 , то получим 0. А если мы вычтем число синонимических рядов, в которые оно входит, то получим $8-3=5$. Можно, конечно, к восьми синонимам прибавить еще 5 - по числу «нулевых» синонимических рядов, образуемых теми 5 значениями, которые не синонимизируются, а потом уже из $8+5=13$ вычесть 8 значений. Тогда тоже получится 5. Но зачем выполнять лишнее действие? Это не рационально. Да и вводить мнимую величину - «нулевой синонимический ряд» запрещает «бритва Оккама»: ведь здесь нет никакой необходимости «множить сущности», и без «нулевого синонимического ряда» вполне можно обойтись. Правда, при вычислении Интегрального Параметрического веса (ИП-веса) «нулевой синонимический ряд» все же понадобится, как было нужно при вычислении С-веса знать количество слов с нулевым числом фразеосочетаний, а при вычислении Э-веса - число слов с «нулевой» многозначностью.

Какую же величину мы получаем в результате такого подсчета? На этот вопрос Ю. А. Стародубцева дала обоснованный и убедительный ответ: «парадигматический вес слов будет зависеть не от числа разных лемм (лексем), а от числа разных ЛСВ (лексико-семантических вариантов) - единств лексемы и семемы» $[24]^{1}$.

Стратификация чеченской лексики по Интегральному параметрическому весу в «Чеченско-русском словаре» Ахмата Гехаевича Мациева представлена в табл. 5.

Наглядно стратификация чеченской лексики по ИП-весу представлена на рис. 6.

Как видим, глубина проработки парадигматики увеличилась всего на единицу, но и это позволило нам уточнить наши представления о парадигматической иерархии лексики.

Так, ИП-доминант у нас уже 2, а не 5, а вице-доминант - 6, а не 20.

${ }^{1}$ В Воронежской научной школе профессора 3. Д. Поповой термины лексема и семема вслед за академиком Н. И. Толстым понимаются как означающее (в словаре - лемма) и означаемое (в словаре - дефиниция, состоящая из последовательности метаслов). 
Т а бли ц а 5

Стратификация чеченской лексики по Интегрально-параметрическому весу

\begin{tabular}{|c|c|c|c|}
\hline СинЛСВ & Слов & Накопл. & ИП-вес \\
\hline $\mathbf{6}$ & $\mathbf{2}$ & $\mathbf{2}$ & $\mathbf{0 , 9 9 9 8 5}$ \\
\hline $\mathbf{5}$ & $\mathbf{6}$ & $\mathbf{8}$ & $\mathbf{0 , 9 9 9 3 9}$ \\
\hline $\mathbf{4}$ & $\mathbf{3 0}$ & $\mathbf{3 8}$ & $\mathbf{0 , 9 9 7 1 0}$ \\
\hline $\mathbf{3}$ & $\mathbf{8 8}$ & $\mathbf{1 2 6}$ & $\mathbf{0 , 9 9 0 3 9}$ \\
\hline $\mathbf{2}$ & $\mathbf{3 0 4}$ & $\mathbf{4 3 0}$ & $\mathbf{0 , 9 6 7 2 0}$ \\
\hline $\mathbf{1}$ & $\mathbf{1 1 1 4}$ & $\mathbf{1 5 4 4}$ & $\mathbf{0 , 8 8 2 2 3}$ \\
\hline 0 & 11566 & 13110 & 0,00000 \\
\hline
\end{tabular}

Формально ИП-доминантами являются слова моха' ${ }^{1}$ 'обида' и барз 'куча', но фактически - только моха ${ }^{1}$ 'обида', потому что барз 'куча', как уже говорилось, относится к «грамматике» лексико-семантической системы.

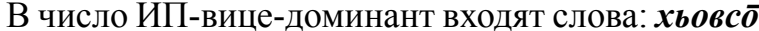
'направить, дать назначение', бъьгазло 'гнев', кхиа 'вырасти, расти', сакx 'наблюдательный', хьажж̄I 'направить', дегабаам 'обида'.

Кроме подкрепления доминантной позиции аксиологемы ч у в с т в о с об с т в е н н о г д ос т о и н с т в а, г о р д о с т ь словом дегабаам' 'обида' и удвоенной представленности аксиологемы ц е-

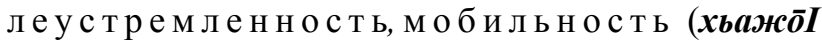
'направить', хвовсо 'направить, дать назначение'), среди ИН-вице-доминант мы обнаруживаем новую аксиологему чеченской ментальности: с п р а в е дл и в о с т ь, инверсно представленную словом ӧьгІазло 'гнев': «Гнев - отрицательно окрашенный аффект, направленный против испытываемой несправедливости, и сопровождающийся желанием устранить еe». Правомерность такого понимания концепта «гнев» подтверждает его сочетаемость: Божий гнев, праведный гнев, народный гнев.

1,20000

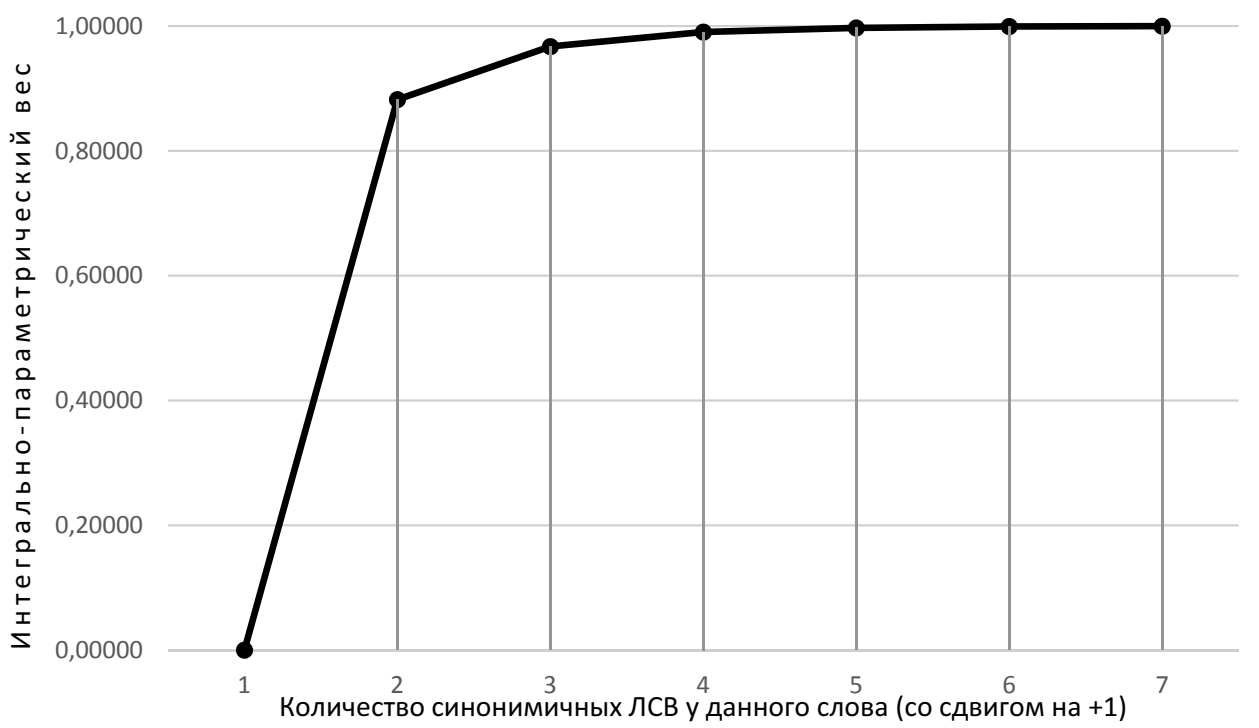

Puc. 6. Стратификация чеченской лексики по ИП-весу в словаре-источнике

Слово кхиа 'вырасти, расти' в равной мере может относиться к семье (о детях), животноводству (о животных) и растениеводству (о растениях: злаках, овощах и плодах).

Размер ИП-ядра составляют 1544 слов, имеющих не менее одного синонимического ЛСВ.

\section{Интегральная параметрическая стратификация чеченской лексики}

Осуществив стратификацию чеченской лексики по функциональному, синтагматическому, парадигматическому и эпидигматическому параметрам, мы создали предпосылку для параметрического анализа чеченской лексики. Теперь у нас есть все необходимое для вычисления интегрального параметрического веса каждой чеченской лексемы, представленной в словаре-источнике. Данное вычисление основано на суммировании 4 частнопараметрических весов (Ф_весв, ИП-веса, С-веса и Э-веса) каждого слова, представленного в словаре. Правда, делать этого мы не будем: по каждому из параметров мы выделяли частнопараметрическое ядро. И участвовать в «слиянии» будут только те слова, которые хотя бы по одному из параметров попали в частнопараметрическое 
ядро, содержащее не менее 1000 слов с максимальным частнопараметрическим весом.

Таким образом, в процедуре вычисления интегрального параметрического веса (И-веса) будут участвовать: 1693 слова, составляющих функциональное ядро, 2971 слово, составляющее синтагматическое ядро, 1544 слова, составляющих интегрально-парадигматическое ядро, и 1717 слов, составляющих эпидигматическое ядро чеченской лексики по данным словаря-источника. Результаты системной стратификации словаря-источника представлены в табл. 6.
В словаре-источнике заявлено 20000 слов. Но при создании базы данных в нее были включены только те словарные статьи, которые соответствуют требованиям параметрического анализа лексики, т. е. содержат необходимую для ПАЛа информацию. При параметрическом анализе лексики отсев части словарных статей - естественное явление.

Доминантой, т. е. главным, вершинным словом в словаре-источнике является слово кхиа [кхуьу, кхиира, кхиъна] 1) сознать, сознавать, осознать, осознавать; понять, понимать; шерен гІа̄латех кхиа сознать

Т а б ли ц а 6

Системная стратификащия «Чеченско-русского словаря» А. Г. Мащиева

\begin{tabular}{|c|c|c|c|c|c|c|c|c|}
\hline \multicolumn{4}{|c|}{ Множества } & \multirow{2}{*}{ И-вес округл. } & \multirow{2}{*}{ Слов } & \multirow{2}{*}{ Накопл. } & \multirow{2}{*}{$\%$} & \multirow{2}{*}{ Накопл., \% } \\
\hline Словаря & Большие & Средние & Малые & & & & & \\
\hline \multirow{4}{*}{ Ядро } & \multirow{3}{*}{ Ядро } & \multirow{2}{*}{ Ядро } & Ядро & 4 & 92 & 92 & 1 & 1 \\
\hline & & & Периферия & 3 & 462 & 554 & 4 & 5 \\
\hline & & \multicolumn{2}{|c|}{ Периферия } & 2 & 1434 & 1988 & 13 & 18 \\
\hline & \multicolumn{3}{|c|}{ Периферия } & 1 & 3305 & 5293 & 30 & 48 \\
\hline \multicolumn{4}{|c|}{ Периферия } & 0 & 5804 & 11097 & 52 & 100 \\
\hline
\end{tabular}

свои ошибки; 2) воспринять, воспринимать; усвоить, усваивать; вникнуть, вникать; книгин чула̄цамах дика̄кхиа хорошо воспринять содержание книги; гІуллакхан духёкхиа вникнуть в суть дела; 3) созреть, зреть; Іежжаш кхиъна яблоки созрели; 4) успеть, успевать; цІа кхиа успеть домой; 5) вырасти, расти; буц кхуьу трава растет; со̄юьртахь кхиъна Я вырос в селе; 6) развиться, развиваться; расцвести, расцветать; вайн социалистически промышленность чехка кхиъна наша социалистическая промышленность быстро развилась.

Вице-доминантой чеченской лексико-семантической системы в словаре-источнике является слово $\boldsymbol{m} \overline{\boldsymbol{e}} \boldsymbol{H}^{1}[m O b$, тийра, тийна] 1) успокоиться, успокаиваться; уняться, униматься; бер тийна ребенок унялся; лазар тийна боль успокоилась; мох тийна ветер утих; 2) прекратиться, прекращаться, перестать, переставать; догla мийна дождь перестал.

В малое параметрическое ядро (т. е. в самую сердцевину - в святая святых) чеченского словаря входят также слова: 3 кхаъ 'радостная весть'; 4 кхел 'приговор, судебное решение'; 5 кхоо 'сберечь, беречь'; 6 эхь 'стыд, смущение'; 7 къёра 'признающийся в чем-л.'; 8 ӧза' 'потянуть, потащить ', 9 да̄ла 'кончить, кончать'; 10 хила 'сбыться, сбываться'; 11 aйр 'кожа (выделанная)'; 12 кхеремa 'взойти, всходить (о небесных светилах)'; 13 mIе̄pal 'верхний, находящийся наверху'; 14 maca 'посеять'; 15 кх Ача2 прибыть, прибывать'; 16 xIов 'пуля, снаряд';
17 барт1 уговор, согласие'; 18 лён ${ }^{2}$ 'говорить, разговаривать'; 19 тан 'помириться-мириться, прийти-приходить к согласию'; 20 кІажа 'петля'; 21 сий 'почет, уважение'; 22 бехк 'долг, обязанность'; 23 бал 'кон (в игре)'; $24 \boldsymbol{x a \boldsymbol { a }}^{1}$ 'узнать, знать'; 25 хьакъ 'соответствие'; 26 хьакхо̄ 'замесить'; 27 га 'ветка, ветвь'; 28 ca $^{3}$ 'угол'; 29 юьхьI 'конец'; 30 луьра 'опасный'; $31 \boldsymbol{\kappa} \boldsymbol{x} \overline{\boldsymbol{a}} \mathbf{\varphi} \overline{\boldsymbol{o}}^{2}$ 'израсходоваться, иссякнуть'; 32 maIo 'кивнуть,'; 33 кІон 'горький'; 34 барз 'холм, курган, пригорок, бугор, насыпь'; 35 моха1 раздражительность'; 36 чалx 'куча, ворох'; 37 зуз 'зуд, зудеть, чесаться'; 38 ида 'бегать, бежать'; 39 mIaм 'ручка, рукоятка'; 40 mуn 'база, стан'; 41 чо 'волос, волосы'; 42 дарра 'выкроить, скроить, кроить'; 43 онда 'крепкий, твердый'; 44 ткъес 'гром'; 45 чIо̄гІа 'твердый'; 46 буру 'бур, бурав'; 47 кёг̄ 'копаться, рыться в

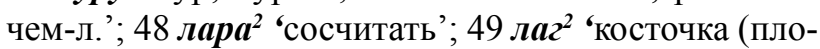
да)'; 50 сакx 'наблюдательный'; 51 вас 'недовольство, претензия'; 52 кІанm 'сын'; 53 кІаг 'лунка, ямка'; 54 увйр 'союз'; 55 дист 'конец, кончик'; 56 зІок 'клюв’; 57 керт 'забор, ограда, изгородь'; 58 къо̄ла 'воровство, кража'; 59 mIёда ${ }^{2}$ 'мокрый, влажный, сырой’; 60 maIa 'прижаться, прислониться'; 61 харш 'морщина'; 62 хедо 'резать, разрезать, нарезать, срезать'; 63 хьёнI 'мять, разминать'; 64 эккха 'прыгнуть ', 65 юург 'пища ', 66 тило 'сбить, сбивать кого-л. (в речи, мыслях и т. п.)'; 67 cal зрение'; 68 mёĪ̄ 'кивать,'; 69 чарх 'механизм'; 70 къАро 'признание'; 71 бен 'гнездо'; 72 кІужс 'чуб, вихор, хохол'; 73 мас 
'волос'; 74 мукъ 'эфес (кинжала, сабли, шашки)'; 75 nax 'пах'; 76 myn' 'кусок, отрез (ткани)'; 77 хІоз 'браслет'; 78 маса 'быстрый, скорый'; 79 Iäм⿻̄⿲㇒丨 'научить, учить'; 80 ӧкъам 'глыба'; 81 диж⿻̄ 'уложить, придать кому-чему-л. лежачее положение'; 82 зёнё 'вредный'; 83 ко̄ча1 жидкий'; 84 кІинж⿻ 'бахрома'; 85 nоmm 'звон, шум в ушах'; 86 тёиа 'убедиться, убеждаться'; 87 mIabхьё 'конец'; $88 \boldsymbol{x y д а ~ ' в с о с а т ь , ~}$ всасывать, впитать, впитывать'; 89 хьёж⿻̄ 'целить, метить'; 90 цуьрг 'крошка (преимущ. хлеба)'; 91 чІа̄ба 'коса (из волос)'; 92 шира 'старинный, древний'.

\section{Заключение}

Подведем итоги. В ходе исследования осуществлена стратификация лексики словаря-источника [12] по длине, количеству фразеосочетаний, значений и синонимичных ЛСВ; выделены функциональное, синтагматическое, парадигматическое и эпидигматическое ядра лексики, размером 1500-3000 слов.

Установлено, что богатством фразеологии обладают преимущественно имена, а богатством значений - преимущественно глаголы.

Интегральная параметрическая стратификация позволила получить малое ядро чеченской лексики размером 92 слова, среднее ядро размером 554 слова и большое ядро чеченской лексики размером 1988 слов. Этот результат имеет как научную значимость (позволяя минимизировать лексику посредством выявления самой богатой системными связями ее части и тем самым делая возможным сопоставить лексико-семантические системы кавказских языков), так и практическую - поскольку дает основания для научно обоснованных методических рекомендаций при обучении чеченскому языку: какую лексику и в какой последовательности следует изучать с детьми в школе (при обучении чеченскому языку как родному), а также в вузах - с иноязычными учащимися, стремящимися овладеть чеченским языком.

Полученные в ходе исследования данные о синонимии чеченской лексики позволили, с одной стороны, создать черновую версию материалов к «Словарю чеченских синонимов с русскими толкованиями», а с другой - выявить духовные ценности (аксиологемы) чеченского народа, нашедшие отражение в его языке. По данным словаря-источника выявлены следующие аксиологемы: справедливость, великодушие, наблюдательность, рассудительность, чувство собственного достоинства, целеустремленность, деятельность, мобильность, оптимизм, удачливость, самообладание, кровное родство, единство, верность, хозяйственность, созидание, здоровье и красота.

В ходе анализа словаря-источника установлено, что функциональными доминантами чеченской лек-

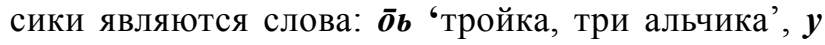
'доска' и ю 'ударник (оружия или орудия)'. Синтаг- матической доминантой является слово бІаьрг 'глаз', представленное 21 фразеосочетанием. Эпидигматической доминантой чеченской лексики (по данным словаря-источника) является глагол кxEma, имеющий 10 значений: «1) взойти, всходить (о небесных светилах); 2) засиять, сиять, светить, излучать свет (о небесных светилах); 3) зайти, заходить (по пути); 4) попасть, попадать в кого, во что-л.; 5) удариться, ударяться обо что-л.; 6) понять, понимать; 7) усвоить, усваивать; 8) освоить, осваивать; 9) заболеть, заболевать; 10) впасть, впадать; втечь, втекать». Интегрально-парадигматической доминантой является слово $\left.\boldsymbol{м o x a}^{1} 1\right)$ раздражительность; 2) обида; недовольство; моха ян обидеться; огорчиться.

Как свидетельствует словарь-источник, «главным» (т. е. самым богатым системными связями) словом чеченской лексики является его интегральная параметрическая доминанта - слово кхиа 1) сознать, сознавать, осознать, осознавать; понять, понимать; шеён гІа̄латех кхиа сознать свои ошибки; 2) воспринять, воспринимать; усвоить, усваивать; вникнуть, вникать; книгин чула̄цамах дика̄кхиа хорошо воспринять содержание книги; гІуллакхан духёкхиа вникнуть в суть дела; 3) созреть, зреть; Іёжаи кхиъна яблоки созрели; 4) успеть, успевать; цІа кхиа успеть домой; 5) вырасти, расти; буц кхуву трава растет; со̄юьртахь кхиъна Я вырос в селе; 6) развиться, развиваться; расцвести, расцветать.

Перспективой данного исследования является параметрический анализ других вайнахско-русских словарей, что позволит со временем создать типологическую классификацию лексико-семантических систем всех кавказских языков, представленных репрезентативными кавказско-русскими словарями.

\section{ЛИТЕРАТУРА}

1. Мациев А. Г. Очерки лексикологии современного чеченского языка / Чечено-Ингуш. науч.-исслед. ин-т истории яз. и литературы. Грозный : Чеч.-Инг. кн. изд-во, 1973. $146 \mathrm{c}$.

2. Исраилова Л. Ю. Англицизмы в чеченском языке : автореф. дис. ... канд. филол. наук. Грозный, 2010. 22 с.

3. Альмурзаева П. Х. Заимствованная лексика чеченского языка : автореф. дис. ... канд. филол. наук. М., 2012. $22 \mathrm{c}$.

4. Сельмурзаева Х. Р. Лексико-семантическое освоение тюркских заимствований в чеченском языке (на материале кумыкского языка) : автореф. дис. ... канд. филол. наук. Махачкала, 2012. 22 с.

5. Юсупова С. С. Новые слова и значения в чеченском языке (постсоветский период) : дис. ... канд. филол. наук. Грозный, 2007. 186 с.

6. Магомедханов М. М. Проблема национально-русской фразеологии. Махачкала : Даг. кн. изд-во, 1988. $130 \mathrm{c.}$ 
7. Байсултанов Д. Чеченско-русский фразеологический словарь. Грозный : Книга, 1992. 320 с.

8. Аджиева И. У. Соматические фразеологические единицы чеченского и русского языков в сопоставительном аспекте : автореф. дис. ... канд. филол. наук. Махачкала, 2013. 24 с.

9. Абдулазимова Т. Х. Синонимы и синонимические отношения в лексике чеченского языка : автореф. дис. ... канд. филол. наук. Махачкала, 2007. 22 с.

10. Ильясова Р. С. Антонимия в современном чеченском языке в сопоставлении с русским языком : автореф. дис. ... канд. филол. наук. Махачкала, 2013. 22 с.

11. Сигаури И. М. Исконная лексика чеченского языка : автореф. дис. ... канд. филол. наук. М., 2011. $20 \mathrm{c}$.

12. Мациев А. Г. Чеченско-русский словарь : около 20000 слов : с прил. краткого грамматич. очерка чечен. яз. / сост. А. Г. Мациев. М. : ГИС, 1961. 629 с.

13. Tuтов В. T. Общая квантитативная лексикология романских языков. Воронеж : Изд-во Воронеж. гос. унта, $2002.240 \mathrm{c}$.

14. Титов B. T. Частная квантитативная лексикология романских языков. Воронеж : Изд-во Воронеж. гос. ун-та, 2004. $552 \mathrm{c.}$

15. Кретов А. А., Меркулова И. А. Динамика и устойчивость в лексической системе славянских языков // Динаміка та стабільність лексичних і словотвірних систем слов'янскьких мов. Тематичний блок. XIV Міжнародний з’їзд словістів. 10.09-16.09.2008, Охрид, Республіка Македонія. Київ, 2008. С. 39-65.

16. Кретов А. А., Меркулова И. А., Титов В. Т. Проблемы квантитативной лексикологии славянских языков // Вопросы языкознания. 2011. № 1. С. 52-65.

17. Воевудская О. М. Концепция идеографического словаря основного лексического фонда германских языков. Воронеж : НАУКА-ЮНИПРЕСС, 2015. 343 с.

18. Кретов А. А. [и др.]. Единство Европы по данным лексики : монография. Воронеж : Издательский дом ВГУ, 2016. 412 c.

19. Меркулова И. А. Лексическая нуклеология славянских языков : автореф. дис. ... д-ра филол. наук. Тверь, 2018. 35 с.

20.Zipf G. K. The Psycho-Biology of Language : an introduction to dynamic philology. Cambridge : Mass. MIT Press, 1965. $336 \mathrm{p}$.

21. Дешериева Т. И. Нахские языки // Языки мира. Кавказские языки. М. : Academia, 1999. С. 166-173.

22. Дешериева Т. И. Чеченский язык // Языки мира. Кавказские языки. М. : Academia, 1999. С. 173-186.

23. Алексеев M. E. Нахско-дагестанские языки // Языки мира. Кавказские языки. М. : Academia, 1999. С. $156-166$.

24. Стародубиева Ю. А. Параметрическое ядро лексики русского языка по данным «Словаря русского языка в 4 томах» под редакцией А. П. Евгеньевой (2-е изд.) : дис. ... канд. филол. наук. Воронеж, 2018. $275 \mathrm{c}$.

\section{REFERENCES}

1. Matsiev A. G. Essays on the lexicology of the modern Chechen language [Text] / Chechen-Ingush. scientific researcher Institute of History and literature. Grozny: Chech.Ing. Prince Publishing House, 1973. 146 p.

2. Israilova L. Yu. Anglicisms in the Chechen language: abstract. diss. ... cand. filol. sciences. Grozny, 2010. 22 p.

3. Almurzaeva P. H. The borrowed vocabulary of the Chechen language : abstract. diss. cand. filol. sciences. Moscow, 2012. 22 p.

4. Selmurzaeva K. R. Lexical and semantic development of Turkic borrowings in the Chechen language (based on the Kumyk language) : abstract. diss. ... cand. filol. sciences. Makhachkala, 2012. 22 p.

5. Yusupova S. S. New words and meanings in the Chechen language (post-Soviet period): dissertation ... cand. filol. sciences. Grozny, 2007. 186 p.

6. Magomedkhanov M. M. The problem of nationalRussian phraseology. Makhachkala: Dag. Prince publishing house $1988.130 \mathrm{p}$.

7. Baysultanov D. Chechen-Russian phraseological dictionary. Grozny: Book, 1992. 320 p.

8. Adzhieva I. U. Somatic phraseological units of the Chechen and Russian languages in a comparative aspect : abstract. diss. ... cand filol. sciences. Makhachkala 2013. $24 \mathrm{p}$.

9. Abdulazimova T. Kh. Synonyms and synonymic relations in the vocabulary of the Chechen language : abstract. diss. ... cand. filol. sciences. Makhachkala, 2007. 22 p.

10. Ilyasova R. S. Anthony in the modern Chechen language in comparison with the Russian language : abstract. diss. ... cand. filol. sciences. Makhachkala, 2013. 22 p.

11. Sigauri I. M. The native vocabulary of the Chechen language : diss. ... cand. filol. sciences. Moscow, 2011.20 p.

12. Matsiev A. G. Chechen-Russian Dictionary: About 20,000 words: From adj. brief grammar Chechen essay. lang / comp. A. G. Matsiev. Moscow: GIS, 1961. 629 p.

13. Titov V. T. General Quantitative Lexicology of Romance Languages. Voronezh: Publishing house of Voronezh. state University, 2002. 240 p.

14. Titov V. T. Private quantitative lexicology of Romance languages: Monograph. Voronezh: Publishing house of Voronezh. state University, 2004. 552 p.

15. Kretov A. A., Merkulova I. A. Dynamics and stability in the lexical system of Slavic languages. In: Dynamics and stability of lexical and word systems of words's words. Thematic block. XIV International Congress of Words. 10.09. September 16, 2008, Ohrid, Republic of Macedonia. Kyiv, 2008. Pp. 39-65.

16. Kretov A. A., Merkulova I. A., Titov V. T. Problems of quantitative lexicology of Slavic languages. In: Questions of linguistics. 2011. No. 1. Pp. 52-65.

17. Voevudskaya O. M. The concept of the ideographic dictionary of the main lexical fund of Germanic languages. Voronezh: SCIENCE-UNIPRESS, 2015. 343 p. 
18. Kretov A. A. and others. The unity of Europe according to vocabulary: monograph. Voronezh: Voronezh State University Publishing House, 2016. 412 p.

19. Merkulova I. A. Lexical nucleology of Slavic languages : abstract. diss. ... doctor. filol. sciences. Tver, 2018. $35 \mathrm{p}$.

20. Zipf G. K. The Psycho-Biology of Language: an introduction to dynamic philology. Cambridge: Mass. MIT Press, 1965. $336 \mathrm{p}$.

21. Desherieva T. I. Nakh languages. In: Languages of the world. Caucasian languages. M.: Academia, 1999. Pp. 166-173.

Воронежский государственный университет Кретов А. А., доктор филологических наук, профессор кафедры теоретической и прикладной лингвистики

E-mail: kretov@rgph.vsu.ru

Черечеча А. Д., студент

E-mail:www.nastyach@mail.ru

Поступила в редакичию 22 ноября 2020 г

Принята к публикаичи 29 декабря 2020 г.

\section{Для цитирования:}

Кретов А. А., Черечеча А. Д. Параметрический анализ чеченско-русского словаря // Вестник Воронежского государственного университета. Серия: Лингвистика и межкультурная коммуникация. 2021. № 1 . C. 123-137. DOI: https://doi.org/10.17308/lic.2021.1/3246
22. Desherieva T. I. The Chechen language. In: Languages of the world. Caucasian languages. M .: Academia, 1999. Pp. 173-186.

23. Alekseev M. E. Nakh-Dagestan languages. In: World Languages. Caucasian languages. M.: Academia, 1999. Pp. 156-166.

24. Starodubtseva Yu. A. The parametric core of the Russian language vocabulary according to the "Dictionary of the Russian language in 4 volumes" edited by A. P. Evgenieva (2nd ed.) : diss. ... cand. filol. sciences. Voronezh, 2018. $275 \mathrm{p}$.

Voronezh State University

Kretov A. A., Doctor of Philology, Professor of the Theoretical and Applied Linguistics Department

E-mail: kretov@rgph.vsu.ru

Cherechecha A. D., Student

E-mail:www.nastyach@mail.ru

Received: 22 November 2020

Accepted: 29 December 2020

\section{For citation:}

Kretov A. A., Cherechecha A. D. Parametric analysis of the Chechen dictionary. Proceedings of Voronezh State University. Series: Linguistics and Intercultural Communication. 2021. No. 1. Pp. 123-137. DOI: https://doi.org/ 10.17308 /lic.2021.1/3246 